\title{
Metastatic Round Cell Liposarcoma
}

National Cancer Institute

\section{Source}

National Cancer Institute. Metastatic Round Cell Liposarcoma. NCI Thesaurus. Code C148300.

Round cell liposarcoma that has spread to other anatomic sites. 